\title{
Do impolitico ao das Politische: NOTAS SOBRE UM DIÁLOGO AUSENTE ENTRE Roberto Esposito E Carl SchmitT
}

\author{
Deyvison Rodrigues Lima
}

\begin{abstract}
Resumo: Este artigo analisa a categoria de impolitico de Roberto Esposito. Tem por objetivo demonstrar a relação entre os conceitos de impolitico e de das Politische. Inicialmente, a pesquisa explora a categoria de impolítico e demonstra alguns pressupostos não assumidos em relaçáo ao pensamento de Carl Schmitt. Em seguida, insere Schmitt na tradição impolítica reconstruída por Esposito e elabora algumas consideraçôes sobre as características impolíticas do das Politische. Ao demonstrar, como resultado, um ponto cego na análise espositiana, qual seja, a ausência de um capítulo necessário sobre o jurista alemão, chega à conclusão de que (i) Esposito elabora uma refinada interpretação da obra de Schmitt, resolvendo alguns problemas de transição, na obra do autor, na década de 1920, porém, oblitera sua influência; (ii) propôe uma leitura que afasta Schmitt da teologia política, ao vinculá-lo à tradição impolítica e esboça a relação entre impolitico e das Politische.
\end{abstract}

Palavras-Chave: : Impolítico. Neutralização. Político. Antagonismo.

\section{CONSIDERAÇÓES INICIAIS}

A questão surge na leitura da obra de Roberto Esposito, mais especificamente, no texto Categorie dell'impolitico (Categorias do impolítico): a compreensão do impolitico como aquilo que é ininstitucionalizável, irrepresentável, vazio, borda ou fronteira da política. Essa tese aponta para o avesso da identidade política como substância e da legitimidade como fundamentação racional ou normativa. A linhagem do impolítico parte de Romano Guardini até Georges Bataille, numa cadência convincente ao atacar o conceito de representação e de ação política. A hipótese exposta neste artigo, porém, sustenta que Esposito reverbera de maneira mais íntima do que assume alguns argumentos propostos por Carl Schmitt, sobretudo, no Der Begriff des Politischen (O conceito do político). Esses pressupostos não assumidos explicitamente

1 Professor Adjunto da Universidade Federal do Piauí (UFPI), Teresina, PI - Brasil. E-mail: deyvisonrodrigues@yahoo.com.br

Doutor em Filosofia pelo Programa de Pós-Graduação em Filosofia da Universidade Federal do Rio de Janeiro (UFRJ).

http://dx.doi.org/10.1590/0101-3173.2018.v41n2.06.p95

This is an open-access article distributed under the terms of the Creative Commons Attribution License. 
acenam para as teses da diferença política como relação, do problema da finitude da ação, da ausência de fundamento, da inevitabilidade do conflito e da impossibilidade de juridificação do político. Na segunda parte, propôe-se uma espécie de capítulo ausente na reconstrução do impolítico, ao se demonstrar que, apesar da inspiração anti-schmittiana (o título Categorie dell'impolitico é uma referência à Le categorie del 'politico', tradução para o italiano de uma coletânea de textos de Schmitt, na qual consta o Der Begriff des Politischen), o livro carrega algumas de suas teses. Nesse contexto, destaca-se uma variação do conceito de das Politische, no final da década de 1920, e sustenta-se que, embora não haja coincidência entre das Politische e l'impolitico, a complementação proposta à tese de Esposito realça os argumentos de Schmitt, na teoria política contemporânea, inclusive, como um capítulo na ruptura da simetria entre imanência e transcendência.

A chave de interpretação da política moderna é descrita por Esposito como uma imunização do corpo social pela neutralizaçáo do conflito, através de um processo de institucionalização do político. Esse paradigma imunitário busca repelir a violência constitutiva das relaçóes sociais, a partir da proteção da vida, e impedir a potencial deriva comunitária como ameaça do munus, isto é, o comum que provoca a perda e a ausência entre os sujeitos. Além disso, o autor demonstra como essa relação desapropriadora é rejeitada na instauração da ordem jurídica e da unidade política, por meio dos mecanismos de representação e soberania: a modernidade assumiu os direitos subjetivos como fundamento da ordem e evitou o contato direto entre os indivíduos, com a exclusividade do liame jurídico. Assim, reduziu a possibilidade de contágio ou violência, pois não haveria relação válida que não seja mediada pela forma jurídica. Nesse ponto, inicia-se a análise das categorias do impolítico. O diagnóstico refere-se à imunização da filosofia política que não pusera ainda em discussão a questão sobre a possibilidade de enunciação de seu objeto e preserva quase sem alteraçóes a semântica moderna de conceitos como soberania, autoridade, representação, entre outros. Este é o mérito inicial do texto de Esposito, qual seja, a problematização do não dito em política ou do princípio como crise que não se situa nem além nem 
aquém, mas sempre como origem presente, ou melhor, como não-origem da política que a filosofia se recusa abordar.

$\mathrm{Na}$ introdução do Categorie dell'impolitico, Esposito confirma a suspeita sobre a influência na proposta do termo: ele afirma que ou bem haveria confusão entre os intérpretes com o termo proposto por Thomas Mann (1974), em Betrachtungen eines Unpolitischen (Consideraçôes de um impolítico) de 1918, ou bem com o texto já citado Der Begriff des Politischen, de Schmitt. Apesar de rejeitar ambas as filiaçóes, o autor afirma que se aproxima da obra schmittiana mais como "ponto de partida [sponda di contrasto] [...] do que uma referência interna.” (ESPOSITO, 1999, p. 7). Há, todavia, um problema a ser analisado: parece que o conceito do impolítico não apenas "começa ali onde o discurso schmittiano para: tomando o que está além [dalla sua ulteriorità]" (ESPOSITO, 1999, p. 7), mas toma emprestado mais do que assume quanto à estrutura, por mais que avance para além do que o jurista alemão admitiria. Entretanto, de maneira desconcertante, a análise de Esposito sobre o impolítico não chega ao Der Begriff des Politischen, apesar de tê-lo em vista. O autor italiano reconhece as "consideráveis realizaçōes analíticas" (ESPOSITO, 1999, p. 7) da Politische Theologie (Teologia política), de 1922, e do Römischer Katholizismus und politische Form (Catolicismo Romano e forma política), de 1923; porém, nesse percurso, ele considera como semelhantes teses bastante distintas, pois a concepção do político como mediação ou representação sofre revisão com a proposta do político como relação ou antagonismo das obras posteriores. Embora demonstre essa alteraçáo como um contra-ataque schmittiano às concepçóes imanentistas da década de 1920, Esposito trata apenas da Verfassungslehre (Teoria da Constituição), de 1928. A questão é: por que Esposito reconhece o Categorie dell'impolitico como mise en abyme do texto Römischer Katholizismus und politische Form e não aborda o Der Begriff der Politischen? A análise aponta que entre impolitico e das Politische há uma conexão importante esquecida. Além disso, a pesquisa joga em cena o conceito de representação: a partir da politische Kehre schmittiana, remete-se àquilo que Esposito observou como sendo o impolítico, ou seja, o irrepresentável da política. Essa virada ficou sem observação devida pelos intérpretes, porém, é precisamente esse argumento que mostra que o desenvolvimento de Esposito passa necessariamente por Schmitt.

Ao distinguir o impolítico do antipolítico ou do apolítico, Esposito sustenta que, enquanto estes participam da política como uma imagem invertida e, como tal, apenas mais uma maneira de fazer política, ao posicionar-se 
contra a política, quer dizer, uma configuração política tanto da antipolítica quanto da apolítica, o impolítico, ao contrário, provoca uma paradoxal intensificação da política, uma vez que ele "define toda a realidade em termos políticos [...] para o impolítico, não existe uma entidade, uma força, uma potência que possa opor-se à política" (ESPOSITO, 1999, p. XIV), com base em algum âmbito externo ou interno, pois não há a possibilidade de um ideal ou valor distintos da realidade política que reconduza à unidade ou origem. Esposito tem em vista os processos de despolitização e neutralização da política que possuem a função de excluir o conflito e instaurar ordem: a política moderna surgiu, então, como antipolítica. Isso significa que o impolítico não se contrapóe à política, nem mesmo pode ser considerado como apolítico ou não-político, porque seria o outro da representação política, isto é, o não pensado ou esquecido por ela: se a política moderna surgiu como antipolítica, pois administração do conflito sob a forma da ordem contra o conflito insustentável da violência anárquica da origem sempre presente, o impolítico não rejeita o conflito nem nega a política, mas "a considera como a única realidade e toda realidade” (ESPOSITO, 1999, p. XV, grifo do autor), ou seja, não existiria fora nem anti- ou ante-, mas apenas política sem possibilidade de metapolítica e, por conseguinte, o impolítico demonstra sua abertura como abandono da simetria entre finito e infinito: considera que não há transcendência ou finalidade externa. Ora, nesse momento, percebe-se o incômodo do impolítico, já que "a política nem sempre tem consciência de sua própria finitude constitutiva. Está continuamente levada a esquecê-la. O impolítico não faz outra coisa que lembrar-lhe." (ESPOSITO, 1999, p. XVI). Assim, o impolítico contradiz não apenas a distinção entre essência e aparência, mas também os discursos de dualidades ou simetrias ao reafirmar um realismo político, uma vez que não há "presença de uma realidade segunda, ou primeira, a respeito da única que se pode experimentar como tal” (ESPOSITO, 1999, p. XXI) e, dessa forma, coincide com a própria política: enquanto a antipolítica ou a apolítica nega a política, o impolítico nega essa negação e, por esse modo, "começa a emergir o caráter paradoxalmente afirmativo da negação impolítica. O que afirma o impolítico? Afirma que não há outra política que a política [...] não é outra coisa que si mesma." (ESPOSITO, 1999, p. XVI).

Nesse contexto, o impolítico serve para afirmar que a política não pode transcender a si mesma, não há nada exterior ou finalidade transcendente nem uma lei natural universal a partir da qual se concede autoridade, ou seja, o “impolítico é o fim de todo "fim da política”" (ESPOSITO, 1999, p. XVI), portanto, como uma desconstrução que, ao contrário, não apenas mostra os 
limites e separa dentro e fora, todavia, "une justamente o que separa", isto é, o impolítico torna-se limite da política, mas também limite de seu próprio limite: "O impolítico não é distinto do político [sic da política], mas sim é o político [sic a política] mesmo observando desde um ângulo de refração que o modera frente ao que ele não é e tampouco pode ser. A seu impossível." (ESPOSITO, 1999, p. XXI). Apesar de rigoroso na utilização dos conceitos, Esposito não distingue entre a política e o político. Essa distinção inaugurada por Schmitt (die Politik e das Politische) e retomada de diversas formas por autores como Paul Ricoeur e Claude Lefort remete à diferença entre uma concepção de política institucional e outra que não é abarcável por instituições, por se referir à transformação e ao conflito. Essa distinção pode ser compreendida como expressão da filosofia diante da crise do pós-guerra, no caso, como um sintoma de ausência de fundamento e finitismo que expõe a dimensão da instituição a situações de rupturas, interrupçôes ou momentos extraordinários, os quais destituem qualquer tentativa de fundamentação do poder, por exemplo, em Helmuth Plessner, como kairós, em Walter Benjamin, como Jetztzeit, ou em Schmitt, como Ausnahmenzustand. Neste último, em Der Begriff des Politischen, a primazia do político, isto é, do antagonismo, demonstra que este é o que mais se aproxima como fundamento da normalidade. Numa inversão elegante, Schmitt sustenta que a ordem pressupóe o conflito, porém, esse conflito mostra-se como negatividade que náo é capturável, quer dizer, porque a possibilidade do conflito, enquanto critério do político, é sempre presente, ele se mantém como a relação doadora de sentido, numa palavra, a abertura constitutiva da ordem. Ao invés de substância, dualidade, objeto ou sujeito, consideram-se relação e diferença, negatividade e conflito, na constituição do poder, ou seja, a transcendência é sempre da ou na imanência, o que desfaz a necessidade do nexo entre ser e aparecer, substituindo-o pelo par político (ou impolítico) e política. Entretanto, Esposito não enxergou nas teses de Schmitt uma ocorrência do impolítico e elaborou, de fato, uma crítica contundente ao jurista.

$\mathrm{Na}$ desconstrução impolítica, há uma negação da teologia política tradicional (católica) como representação ou conexão entre terra e céu ou poder e bem, mas também rejeição da teologia política, seja compreendida como filosofia da história, seja compreendida como transferência ou secularização de conteúdos teológicos para conceitos jurídico-políticos. $\mathrm{O}$ impolítico não repete a postura da filosofia política moderna de pressupor uma origem ou substância, seguida por uma cisão ou crise que determina a reflexão nostálgica sobre fundamento perdido ou instauração de um processo de despolitização 
e neutralização. Para Esposito, não há movimento linear; desde o começo, a cisão e o conflito são concebidos como origem, embora afirme que "não é necessário decidir disto que a política não tem propriedade nem essência [...] sua propriedade consiste na ausência do próprio, assim como sua essência consiste em uma falta de essencialidade irremediável." (ESPOSITO, 1999, p. XXVI). Ele assume o impolítico como de-criação e desfundamento: se não há queda nem origem, então princípio e o precipício são originários, tal como um descentramento, sem dúvidas, uma desconstrução da lógica moderna, mesmo que partindo dela mesma. Assim, Esposito aproxima-se de Heidegger, ao afirmar que "a origem não se dá senão na forma do próprio apartar-se" (ESPOSITO, 1999, p. XXVII) e, por conseguinte, não considera um processo histórico determinado por algo anterior ou por uma finalidade, como nas teses da secularização, mas analisa a política naquilo que não é exposto, como que desocultando seu parti pris: demonstra que não é possível dar a volta por trás e encontrar algo como essência ou fundamento - argumento que retorna em obras posteriores, como Communitas (1999) e Immunitas (2002) -, já que dar a volta por trás é como dar uma volta em torno de uma mesa, pois se encontra, após a volta, no mesmo lugar de antes. A origem seria secundária, ou seja, seria não-origem, pois diferença de si mesma, articulação in-originária daquilo que se origina. Como não é possível dar a volta por trás, para desvelar um fundamento e, ao tentar esse movimento, a reflexão encontra uma origem não originária, percebe-se que a origem coincide com a não origem. Esposito considera que nisto consiste o irrepresentável da política, e o impolítico seria a enunciação desse irrepresentável. Este provocaria um curto-circuito na noção de representação: se a origem é crise-princípio, mostra-se a cada tentativa de delimitação como um retrair-se contínuo, não como algo que está fora ou além, no entanto, como um limite, margem ou vazio exterior que a política não determina, mas que é ela mesmo como presença e finitude.

Para os propósitos desta investigação, é suficiente uma leitura seletiva de alguns episódios do texto espositiano. Inicialmente, o autor lança o debate sobre a teoria da representação política no catolicismo do início do século XX, sobretudo, com Romano Guardini e Carl Schmitt. Esse tema serve de problema inicial, com base no qual o argumento do impolítico é desenvolvido. Para Guardini, segundo Esposito, a teologia política postula a função do Cristo como lugar da decisão: isso significa compreender, no seu sofrimento, a distância e a separação, expressas na narrativa bíblica como abandono. Assim, essa distância, ou melhor, essa cisão revela-se como a própria condição da decisão, ou seja, a oposição ou bipolaridade do contraste que a natureza 
de Cristo carrega. Tal condição afirma a possibilidade da decisão através da oposição entre homem e Deus, natureza e graça, tempo e eternidade. Além disso, compreende essa relação como alteridade e a decisão como histórica, pressupondo-a como vinculação entre poder e autoridade, imanência e transcendência. A fim de que haja autoridade, porém, é necessário que uma pessoa concreta a represente visível e historicamente, seja como homem singular, seja como instituição, em todo caso, como uma representação na história ou encarnação. Não basta à autoridade a decisão, pois necessita da referência ao elemento transcendente: além do sujeito ou da instituição, é preciso haver uma conexão ou liame entre céu e terra ou bem e poder. Em suma, aqui reside a teologia política católica, como uma política metafísica da uniáo ou representaçáo entre o terreno e o divino. Ao mesmo tempo, rejeita as teses protestantes do governo divino imediato e a doutrina da sola scriptura, bem como as teses dos humanistas e dos defensores das ragioni di stato, numa curiosa declaração católica contra os inimigos comuns, Lutero e Maquiavel. Em Guardini, portanto, dá-se a expressão dessa declaração: além da instância concreta e histórica, a transcendência da ideia em função da qual se representa e se organiza a realidade garante validade à autoridade política.

Em Schmitt, por contraste, não há relação teológica substancial: a mediaçáo da Igreja funciona como um modelo apenas formal, uma vez que assume de Roma o paradigma jurídico-político de organização do poder, qual seja, a exigência de dar forma à vida, de uma razão ordenadora expressa como complexio oppositorum, isto é, uma estrutura que abarca e reúne as contradiçóes do social, reduzindo os dualismos modernos ou pluralidades concretas, ao estabelecer uma realidade institucional como unidade e ordem formal. A teologia católica seria portadora de um racionalismo jurídico como uma função sacerdotal universalizada que se caracteriza pela representação: esta é a forma ou ideia do direito que a Igreja realiza, por sua capacidade de conceder unidade à realidade humana, sem reduzir a experiência material a esquemas abstratos. O sacerdote é concretamente interligado por uma cadeia de mediaçóes e representa a pessoa de Cristo, na relação entre céu e terra. Essa representação empresta à Igreja a capacidade de criar direito, em outras palavras, auctoritas. A mediação seria o principal atributo da Igreja: é o que possibilita a jurisdictio da autoridade. Nessa estrutura, a função do político é, via teorema da secularização como problema teológico-político - isto é, a Igreja como modelo para o Estado -, apenas secundária, qual seja, realizar a mediação do teológico, pois o poder só tem autoridade, caso represente e sirva de mediação dessa forma estabilizadora. Este é o primeiro aspecto da questão que Esposito considera 
em Schmitt: o político como mediação é a tese central da teologia política. A relação se estabelece entre decisão soberana e ordem de direito, poder e autoridade, uma bipolaridade típica do catolicismo que se opóe ao pensamento imanentista ou não representativo. Schmitt afirma, em Römischer Katholizismus und politische Form: "Nenhum sistema político pode durar, nem sequer uma geração, como uma técnica da conservação do poder (Machtbehauptung). A ideia é inerente ao político (zum Politischen gehört die Idee), dado que não há política sem autoridade, nem há autoridade sem um ethos da convicção." (SCHMITT, 2008, p. 28). Esposito retoma a argumentação schmittiana do complexio oppositorum como crítica à técnica moderna e aos dualismos incapazes de dar forma política, porque mero domínio da matéria que reproduz as fraturas entre espírito e natureza, pensamento e ser, sujeito e objeto do racionalismo técnico-científico: a complexio seria uma estrutura ou ordo geométrico-representativo da Igreja, em formato de cruz, vertical-horizontal, uma extensão horizontal governada por uma decisão vertical que pressupóe a ideia ou forma jurídica, para ordenar e hierarquizar as diferenças concretas. É um argumento que garante ordem e forma à experiência, mas não dissolve as contradiçôes do corpo social: surge uma instância de representação como totalidade. Nesse momento, ainda não há realismo político, mas a tentativa de orientar normativamente a ordem, por intermédio de uma racionalidade institucional, um modelo eclesiástico pelo qual a existência concreta (contingente) se torna racional (organização política). A decisão é orientada pela representação e busca instituir a ordem, em suma, eis a tese teológica-política schmittiana, a qual ainda não concebe o político como algo autônomo.

Essa estrutura torna-se problemática quando Schmitt abandona a possibilidade de dar forma à experiência, a partir de uma instância decisória concreta orientada normativamente. Para isso, é necessário distinguir a evolução do conceito de representação, em sua obra de 1923 até 1928, e esclarecer que a ausência da análise do Der Begriff des Politischen por Esposito náo é insignificante: a concepção católica da complexio enquanto diferença horizontal que une contrários e a transcendência da ideia enquanto diferença vertical, que garante autoridade, dão lugar, na modernidade, à concepção democrático- parlamentar que elide a dimensão da transcendência. Nesse caminho, um novo conceito do político surge como crítica às dualidades da modernidade, mas também ao continuum entre religiâo e política. Assim, Esposito realiza uma leitura correta, ao afirmar que,

desde o escrito de 1923 ele [Schmitt] considera a ideia propriamente católica de representaçáo e, portanto, todo horizonte categorial do catolicismo, 
em termos residuais, como o que resiste; e ao convergir contra ele, de forças opostas e complementares como o capitalismo e o socialismo. Isto significa que o catolicismo poderia obter o monopólio do político, justamente porque tenha ficado só em sua defesa [...] Daí seu destino terrivelmente utópico, no sentido literal de uma crescente subtração do espaço histórico e semântico, de uma progressiva e irrefreável insularidade frente ao grande desenraizamento moderno. (ESPOSITO, 1999, p. 54).

Nos textos iniciais do período weimariano, há uma Trennungsthese que vincula a forma de direito à decisão concreta, para efetivar a ordem como jurídica, ou seja, segundo Schmitt, não é possível pensar o direito sem uma instância concreta e anterior, numa palavra, soberania. Entretanto, essa decisão soberana pela ordem não pode ser determinada normativamente, uma vez que a tese da articulação entre exceção e norma revela o primado da decisão do soberano: "A ordem jurídica, como toda ordem, repousa em uma decisão e não em uma norma." (SCHMITT, 2004, p. 16). Essa tese reforça a decisão como organizadora da realidade, já que a norma a pressupóe, isto é, reconhece seu poder de normalização da faticidade, e somente em um momento posterior adviria sua legitimidade. Apesar de manter a diferença entre transcendência e imanência como distinção entre Recht (direito) e Rechtsverwirklichung (realização do direito), Schmitt assume a ação soberana como contingente ou indeterminada e, por conseguinte, deixa frouxa a relação da mediação política do teológico, a qual garantiria a representação da ideia na experiência: afinal, desliga a relação entre transcendência da forma e a imanência da decisão. Nesse contexto, Esposito tem o mérito de sustentar uma interpretação da transformação do pensamento de Schmitt, ao perceber esse abandono da bipolaridade que caracteriza a representação católica, sobretudo, ao apostar que a dualidade entre forma de direito e decisão concreta é reavaliada como algo imanente. Tal transformação seria motivo de ataques de teólogos contra Schmitt: a secularização levou-o à imanência, portanto, uma secularização que não apenas transferia, mas eliminava a mediação do teológico pelo político, agora autônomo:

O caráter irreversível da secularização está confirmado pelo fato de que justamente ao remeter à autoridade pessoal do Cristo age, no aparato conceitual do Hobbes schmittiano, como legitimação da cisão interior/ exterior, e portanto de levar a zero a Veritas transcendente [...] A distância realmente insuperável que separa a teologia política schtmitiana da grande representação católica se manisfesta justamente aqui, na desautorização da transcendência da Veritas. (ESPOSITO, 1999, p. 56). 
Apesar de assegurar que "decisão e representação permanecem como referências fundamentais na obra schmtitiana, porém submetidas a um movimento de secularização que tende a fazer divergir ao infinito seus planos" (ESPOSITO, 1999, p. 56), acentuando a diferença entre Schmitt e a teologia católica, Esposito ressalta a transferência da bipolaridade para o nível da imanência, no caso, como diferença que corresponde à relação concreta descrita como antagonismo ou relação entre amigo e inimigo:

Ambos os termos - unidade e oposição - se voltam absolutos ao externo do poder, e ainda invertem, o significado conferido a eles pelo princípio bipolar, no sentido de que a unidade tende a saturar a diferença metafísica em direção a um acabado monismo, enquanto a oposição, transferida ao nível de imanência tende, reciprocamente, a transformar a diferenciação na antítese, também absoluta, amigo/inimigo. (ESPOSITO, 1999, p. 56).

Ora, aqui se encontra uma sofisticada interpretação das teses schmittianas, sobretudo da transição para as obras do período tardio da República de Weimar. Assim, para Schmitt, desde o período pré-weimariano, o princípio representativo teria surgido na modernidade como uma superioridade formal, mas tal superioridade formal se dá como uma complexio: não elimina a diferença, a forma representativa não sacrifica os opostos concretos e a representação é a garantia ou salvaguarda da pluralidade dos elementos representados, por isso, complexio oppositorum, ou seja, uma estrutura que reúne e guarda, representa os opostos numa solução de hipostasiação da ordem e torna-se, no final das contas, uma crítica aos dualismos modernos, já que a pluralidade é afirmada, ao mesmo tempo que se forma uma realidade institucional. $\mathrm{O}$ elemento transcendente tanto ao representante quanto ao representado é a ideia de direito, o qual tem como característica a formação (Formierung) da realidade: ao político seria inerente a ideia, portadora da autoridade. Ao contrário de um pensamento não-representativo - por exemplo, em Max Weber, na descrição da redução do conceito de autoridade ao conceito de poder -, Schmitt, assim como o catolicismo, conservaria tanto a diferença-horizontal (pluralidade) quanto a diferença-vertical (transcendência). Essa diferença crucial, porém,

rompe-se, quando um de seus polos - o transcendente - é esquecido, quando todo o real se fecha dentro de um único princípio monista, então a grande representação política não pode senão despedir-se e deixa o terreno para seu moderno adversário: "o pensamento econômico conhece somente um tipo de forma, quer dizer, a precisão técnica que está longe da ideia de representaçáo”. (ESPOSITO, 1999, p. 76). 
De acordo com Esposito, o problema da mediação em Schmitt, em meados da década de 1920, enfrentava essa encruzilhada diante da negação imanentista da noção de forma jurídica: ou bem continuava na relação transcendência-imanência como chave para legitimidade política, ou bem combatia o adversário (liberalismo, sobretudo) no seu próprio campo. $\mathrm{O}$ encerramento paradigmático é realizado com o politische Existentialismus (existencialismo político) e resumido por Esposito: "O fim da bipolaridade (entre céu e terra) assinala o fim da representação; o fim da representaçáo, o fim da política." (ESPOSITO, 1999, p. 76). Nesse argumento, Esposito teria em mãos mais uma ocorrência do impolítico, precisamente, no autor que, segundo ele, teria elaborado a última grande defesa da noção de representação, porque, tendo em vista a perda do político como mediaçáo, Schmitt teria proposto uma alternativa imanentista com um renovado conceito do político que se configura de maneira pós-estatal, apesar de ainda propor ordem jurídica e a estabilização do poder. Entretanto, a questáo que se póe é, novamente: por que a leitura que Esposito realiza da alteração da noção de político em Schmitt não chega explicitamente ao Der Begriff des Politischen? Neste momento, o percurso mais adequado apontaria para a virada do político que Schmitt executa, um anúncio da pós-política ou de uma política pós-estatal - pressupondo, por exemplo, a relação de antagonismo como anterior ao Estado ou ainda a representação política como relação imanente à unidade política, como na Verfassungslehre (Teoria da Constituição) - porém, o leitor vê um tema promissor sem desenvolvimento necessário.

Na leitura de Erich Voegelin (1931) sobre Schmitt, segundo Esposito, apresenta-se essa relação entre imanentismo e fim da representação no jurista:

O caráter monista, a caída da bipolaridade, caracterizava o novo ponto de vista schmittiano. É como se Schmitt tivera reduzido drasticamente o alcance diferencial do conceito de representação tal como aparecia no ensaio de 1923. O que ali era cuidadosamente diferenciado, agora está concentrado, violentamente concentrado, em uma obsessão de unidade que não deixa espaço a outro respecto dele. Segundo Voegelin, é justamente essa obsessão a que arrasta o ponto de vista de Schmitt, ainda tão inclinado a romper a falsa coerência da teoria no carater concreto da realidade existencial, até o plano tradicional da abstração. (ESPOSITO, 1999, p. 77).

Para Voegelin, o princípio teológico é o fundamento de sentido e, fora dessa bipolaridade metafísica, o político ficaria perdido - e o mesmo ocorreria com os conceitos de unidade, vontade e decisão. Esse juízo teológico explica 
o motivo das reaçóes hostis que Schmitt sofreu dos católicos. O que interessa, neste ponto, é a acusação de que a Verfassungslehre teria uma postura imanentista contra a transcendentalista da teologia política católica autêntica, a qual rejeita a coincidência entre fundação e autoridade ou a legitimação imanente da ordem. Na desconstrução do conceito de representação de Voegelin, Esposito procura o conceito de Identität em Schmitt e, mais uma vez, o autor italiano pauta os temas schmittianos, inadvertidamente, fora do Der Begriff des Politischen, onde conseguiria melhores resultados. Afinal, embora Esposito apostasse na relação entre Hobbes e Schmitt, ele recua das suas consequências mais radicais: se aquele abre a política moderna, este deveria ser compreendido como final ou fechamento da modernidade política, quer dizer, durante o percurso, a transcendência se perdeu, tornando-se o outro ou, simplesmente, antagonismo. Segundo Esposito, ao eliminar o amor Dei, resta a Hobbes o amor sui, e isso desencadeia a história da imanência na tradição moderna. Assim, a argumentação espositana deveria, para ser coerente, sustentar Schmitt como filósofo da imanentização e a categoria do político do texto Der Begriff des Politischen distinta daquela da Politische Theologie e do Römischer Katholizismus. Essas leituras confirmam a hipótese assumida nesta pesquisa: a obra de Schmitt adotaria uma estratégia de finitude, desenvolvendo-se de um normativismo até um realismo forte, cujas características seriam o monismo e o imanentismo. Esposito reconhece esse movimento ao asseverar:

Daqui, para Schmitt, por um lado, a negação de toda posição nostálgicorestauradora, e portanto a aceitaçáo do horizonte da técnica como o único efetivamente provável; por outro, a recuperação, a partir do interior mesmo da técnica, de seu vazio político, de uma noção de política adequada às circunstâncias, quer dizer, em condiçóes de aceitar o desafio imposto pelo tempo da técnica e de decidi-la existencialmente. Somente uma decisão livre de pressupostos historicistas e esquemas providenciais pode tornar plena a "nada-política" da técnica dirigindo-a para seus próprios fins. (ESPOSITO, 1999, p. 77).

O que Esposito sustenta aqui pode dar uma pista para a compreensão de como Schmitt teria se desfeito da bipolaridade imanência/transcendência e criticado o moderno, como cisão e descontinuidade, abandonando a solução do continuum entre teologia e política. Essa proposta, porém, não é desenvolvida, pois Schmitt desaparece aos poucos do texto de Esposito, para voltar aqui e acolá, entre Heidegger, Jünger e Bataille. Durante o percurso inteiro, o impolítico refere-se à imanência náo como algo distinto 
da transcendência, mas na tentativa de compreensão da política, mais uma vez diante do oxímoro da representação da pluralidade, isto é, ao preferir a afirmação da irrepresentabilidade da política tal como um objeto passível de determinação, mas em função da sua margem exterior e que a determina negativamente, ao mesmo tempo como fundo e reverso. Nesse sentido, o impolítico demonstra a impossibilidade de determinação afirmativa da política e, por conseguinte, a possibilidade da ruptura das simetrias entre transcendência e imanência, tarefa que, segundo a interpretação que é proposta a seguir, Schmitt também desempenha:

O modo do impolítico é esta imanência que remete já à transcendência, uma transcendência escavada na imanência. Não um espaço ou, todavia menos, um valor situado fora do político e a ele indiferente, mas sim o transcender interior ao político como categoria afimativa. O vazio, a ausência que o político abre quando póe em jogo (revoga) sua própria dimensão de presença (representação). $\mathrm{O}$ impolítico consiste em uma saída fora de si mesmo que não se eleve a nenhuma transcendência. (ESPOSITO, 1999, p. 121).

Assim, compreender o impolítico como aquilo que contorna, como uma margem exterior que, ao mesmo tempo é seu fundo e seu reverso, como aquilo que é externo, porém, que simultaneamente limita a política, como um bordear. Essa diferença entre política e seu fundo irrepresentável também ocorre em Schmitt, ao compreender seu conceito do político como relação e antagonismo, como no trecho a seguir: "O inimigo é a nossa própria pergunta enquanto forma e ele nos arrasta, e nós a ele, para o mesmo fim." (SCHMITT, 1991, p. 213). O argumento do impolítico é terreno, desliga céu e terra, não escolhendo algum dos elementos, mas assumindo a tarefa de ruptura das dicotomias, ou seja, uma postura antimetafísica e antiteológica, por isso, o curto-circuito na relação entre sujeito e poder proposto pelo autor italiano. Por um lado, pensar apenas a transcendência significa pensar a ausência e, portanto, uma metapolítica; por outro lado, pensar apenas a imanência também não se mostra a solução mais adequada: recai-se na repetição da unilateralidade, porque o plano de imanência seria absoluto ou infinito e restaria, da mesma maneira, a identidade metafísica. Por isso, não é o caso de afirmação de um polo ou outro, mas da diferença como um rasgo que desfaz a dicotomia entre imanência e transcendência. Essa relação é proposta por Esposito, como impolítico, e por Schmitt, como antagonismo. Expostos alguns comentários 
sobre o impolítico e a interpretação espositiana de Schmitt, resta-nos elaborar o episódio ausente nesse diálogo.

\section{II}

$\mathrm{Na}$ leitura espositiana, a neutralização e a despolitização são elementos da política moderna. Em outras palavras, a institucionalização política como estabelecimento de um excesso normativo que provoca a violência da ordem contra a violência anárquica, através da ação soberana. Paradoxalmente, a estrutura representativa moderna é instaurada por Hobbes, ao mesmo tempo em que se perde a representaçáo da ideia, qual seja, a forma de direito abstrato que o Estado deveria tomar, como mediação para justificar-se como legítimo. O paradigma da representação entre transcendência (ideia) e imanência (força) é transformado em outro que, entretanto, realiza um curto-circuito entre céu e terra, ao instaurar-se como relação entre representante e representado. Para Esposito, seguindo Schmitt, esse modelo de representação revela a negação da mediação entre forma de direito e poder concreto, pois a representação tornou-se imanente. Daí o texto Römischer Katholizismus und politische Form, de 1923, ser uma das derradeiras defesas da representação ou do político como mediação, tema presente também na Politische Theologie, de 1922. Ao perder o vínculo da mediação racionalista, isto é, a referência à ideia de direito como organizadora do Estado, a modernidade tornou-se autoreferencial, pois, sem a determinação de um bem transcendente ou vinculação do poder a uma finalidade externa. A solução do mecanismo da decisão como decisão pela representação, na Politische Theologie, seria uma tentativa para refazer o vínculo autoritativo entre forma e poder. Desligados entre si, a mera força permaneceria carente de legitimidade, por isso, a tese da teologia política schmittiana: uma exceção (decisão) que capta o excesso (forma) e evita uma autofundamentação como afirmação de força. Desse ponto, confissão da crise do Estado, Esposito iniciou sua crítica.

Essa compreensão espositiana, todavia, faz jus às teses de Schmitt até 1923. Assim, se é correto afirmar que Schmitt vincula o político à representação ou mediação, tem-se a decisão pela ideia ou forma de direito (ordem), em meados de 1920; logo em seguida, no final da década, já não é possível compreendê-lo através desstas teses, ou seja, o conceito do político não é mais analisado como mediação, mas como relação concreta e antagonismo anterior 
à unidade ou ordem. Neste ponto, a questão é a seguinte: por que Esposito não analisa a virada do conceito do político e a dissolução da representação moderna que o Der Begriff des Politischen traz? A hipótese proposta é que Schmitt esteja mais próximo do que se poderia aceitar e faz jus ao rol de autores impolíticos ou, ao menos, utilizou alguns argumentos ou estratégias impolíticas. Em outro trecho fundamental, Esposito aproxima das Politische e o impolitico, ao considerar este, assim como Schmitt faz com aquele, como uma

crítica da teologia política em sua dupla acepçáo católico-romana (a representação) e hobbesiano-moderna (a relação entre representante-representado). Nesta segunda direção, o impolítico se constitui em oposição direta a toda forma de despolitizaçáo, e entâo, numa relaçáo simplesmente oposta do político [sic política] [...] o impolítico é o político [sic política] observado desde seu limite exterior [...] Nesta acepção, impolítico tem sido todo grande realismo político. (ESPOSITO, 1999, p. 20).

O filósofo italiano parece desconhecer que essa distinção entre política e impolítico já havia sido feita, em termos aproximados, conforme Oliver Marchart (2010), por Schmitt, com os termos die Politik e das Politische. Em todo caso, é correto pensar o impolítico como uma forma de realismo político e, assim, Esposito fornece a chave para compreensão do problema: a questão do medo e da insegurança é tratada pela política, ao escamotear as relaçóes de dominação e violência sob institutos jurídicos e morais, as quais o impolítico problematiza, quando explicita que não existe outra política que ela mesma. O impolítico, como o irrepresentável da política, é a ação que busca desocultar inimizades e conflitos, como uma desautorização do soberano, das convençóes e da unidade da ordem, aliás, como Maquiavel já havia realizado. Ao assumir, embora com nostalgia, o fim da representação política por conta da despolitização e neutralização da forma política como mediação, Schmitt reconhece uma ausência de fundamento transcendente, um nada ou vazio no centro da política moderna: resta-lhe a ação política como relação concreta que determina o poder: "Todos os conceitos, representaçóes e palavras políticas têm um sentido polêmico, visualizam um antagonismo concreto, estâo ligados a uma situação concreta [...] e transformam-se em abstraçóes vazias [...] quando esta situação é esquecida." (SCHMITT, 2002, p. 31). Essa tese implica um fundamento negativo do agir político, o qual não se submete à determinação jurídica ou racional prévia. Isso significa que não é possível encontrar um fundamento último de legitimação, pois há um abismo no momento constitutivo do político marcado pela contingência. 
Todavia, necessário distinguir, ao menos como um esboço geral, três momentos, no pensamento de Schmitt, para compreender a inserção na tradição do impolítico: (i) o momento formalista, durante a década de 1910 - especialmente, o Der Wert des Staates und die Bedeutung des Einzelnen (O valor do Estado e a importância do indivíduo) - que pode ser denominado como período pré-weimariano; (ii) o momento marcado pelo Die Diktatur (A ditadura) e pelo Politische Theologie, até meados da década de 1920, compreendido como um realismo fraco, pois há decisão e exceção, mas em função da instauração da forma e ordem política, considerado como período weimariano, ainda na defesa da representação ou de uma validade ante rem; e (iii) um momento de realismo forte, sobretudo em Der Begriff des Politischen, mas também em Verfassungslehre, marcado pelo politische Existentialismus (existencialismo político) ou pela compreensão do político como relação e antagonismo, localizado no final da década de 1920 e caracterizado ainda por uma validade in re ou imanentista, pois se refere à relação e a arranjos de forças e afetos. Este último caracteriza-se por um abandono da semântica metafísica da decisão e da exceção, além do político como mediação. Nesse período, a decisão do soberano, enquanto decisão pela realização de um ideal e da ordem no corpo social, é descartada pelo caráter autônomo do político, na diferença imanente. Como consequência, a contingência da realidade, exposta pela decisão, passa a ser considerada o locus da ação política, afastando-se do teorema da secularização ou de uma metapolítica. Esse problema é retomado sob a forma da desestatalização do político: a compreensão de que a instituição é assumida como fenômeno posterior ao político, segundo a tese de que "o conceito do Estado pressupóe o conceito do político." (SCHMITT, 2002, p. 20). Se o argumento do imanentismo ou do finitismo, como interpreta Voegelin (1931), na crítica a Schmitt, recusa a relação entre transcendência e ação política, é imperioso demonstrar como a instância não normativa, irracional, tecida por relaçôes de conflito, precária e contingente, conseguiria determinar o corpo político, sem apelar para uma fundamentação racional. Schmitt não estaria propondo um "estado de natureza", retomando o político como pré-política e pré-estatal? No final das contas, a questão é compreender a condição da ação política, a partir do finitismo, e, para isso, ele assume uma postura pragmática, na qual sustenta a tese de que a constituição do político se dá na diferença do conflito e, por conseguinte, funciona como ininstitucionalizável: o impolítico schmittiano como uma política dos afetos ou, mais precisamente, do afeto mais intenso, o conflito. Desse modo, uma política que se excerce na contingência dos arranjos de forças, e não na decisão 
pela ordem, não escamoteia a violência como origem da ordem. $\mathrm{O}$ desafio é, sem metafísica política, não reduzir a imanência da relação à faticidade. Para tanto, utiliza-se uma estratégia finitista típica do realismo político, que, conforme sustenta esta pesquisa, o torna afim à categoria do impolítico. ${ }^{2}$

No final da década de 1920, Schmitt realizou uma virada política, a qual consistiu no movimento de tentativa de ruptura da distinção entre transcendência e imanência, ao justificar a ação política através desta última. A pressuposição de uma ideia ou forma de direito é abandonada e a legitimidade passa a ser considerada como um problema concreto que implica a existência de contraposiçôes ou antagonismos como condição para a organização política. A questão é sobre a possibilidade da ação política sem critérios racionais (institucionais ou normativos). Aliás, a teoria do político torna-se um sintoma da crise da estatalidade e da ausência de fundamento, ou seja, um deslocamento da questão do sujeito (da decisão) para a relação como diferença e conflito. Nesse quadro teórico, a ação política é singular, dá-se na negatividade e daí assume uma característica desestabilizadora. Ao compreender os dualismos e cisôes schmittianas num grau crescente de concretude e contingência, percebe-se que aquilo que possibilita a ação política não é alheio à própria ação, por isso, a leitura monista ou imanentista: Schmitt é responsável pela ruptura da compreensão normativa da ordem e, ao perceber, resta-lhe como dado bruto a relação de conflito como aquilo que, efetivamente, produz e dá a medida, isto é, a ordem política teria uma validade in re.

Essa distinção, que nas obras anteriores se referia à decisão e forma, exceção e excesso, político e ideia, no Der Begriff des Politischen se transforma em um abismo que revela como algo irrepresentável, incodificável, pois se mostra anterior e, paradoxalmente, o fundamento negativo, como das Politische em contradição com die Politik: este se refere ao poder institucionalizado; aquele, ao conflito, heterogeneidade e pluralidade de relaçóes, constituindo uma dialética entre ordem e conflito. ${ }^{3}$ Ao sustentar a anterioridade e a autonomia do político diante do Estado ou de qualquer paradigma formal ou normativo an-

\footnotetext{
${ }^{2}$ Essa virada finitista de Schmitt pode ser compreendida a partir da influência de Hans Vaihinger; por exemplo, Hasso Hofmann capta isso, ao afirmar: "Er war entschlossen, sich der vom Neukantianismus als bloße Faktizität zurückgelassenen zu stellen und die Wirklichkeit selbst als Rechtswirklichkeit zu konstruieren." (HOFMANN, 2002, p. 87).

${ }^{3}$ Benjamin Arditi traz essa mesma compreensão, ao se referir a Schmitt: "He is advancing a claim that in a way mirrors the ontological difference in Heidegger and brings to mind Claude Lefort's claim that we should not confuse the political with its historical modes of appearance [...] the political in Schmitt will always be excessive vis-à-vis its concrete manifestations.” (ARDITI, 2008, p. 13-14).
} 
terior, Schmitt adota a determinação fenomenológica mais próxima às práticas do que aos conceitos universais ou critérios abstratos da mediação política. Assim, sua Kehre destaca que o político não se restringe ao Estado, uma vez que este é apenas um status ou modo de aparecer hegemônico, uma forma institucional derivada da relação e do conflito e, por essa contingencialidade da forma, pôe em questão a dialética entre ser e aparecer. Essa dialética, própria da estatalidade moderna, esconde a violência na formação da unidade política e busca uma medida transcendente, essência ou origem como condição não política da política, isto é, nega a compreensão da política como conflito e relação por instâncias apolíticas ou morais, ao invés da relação e do sentido concreto. Ao asseverar, por exemplo, que "o político não tem substância própria” (SCHMITT, 1994, p. 160), ele vincula o político à relação. Ora, pode-se afirmar com isso a tese da imediatidade relacional como medida do político, que seria dada a partir de um "critério conceitual" (Begriffsmerkmal) e não por uma "definição de essência” (Wesensbestimmung), ou seja, a autonomia do político, recusando um parâmetro racionalista, refere-se a um critério específico: a relação concreta.

No mesmo movimento de afirmação da indeterminação substancial, da autonomia e do caráter relacional, o critério político é designado ainda pelo grau de intensidade das relaçóes e afetos dos corpos em associação e dissociação, levando em conta a possibilidade de morte. Essa postura pragmática dá primazia ao existencial e altera seu conceito de legitimidade: "A oposição política é a oposição mais intensa e mais extrema e qualquer situação de oposição concreta é tão mais política quanto mais se aproxima do ponto extremo que é o agrupamento entre amigos e inimigos." (SCHMITT, 2002, p. 30). Assim, o político refere-se ao corpo social como relação imediata tomada como existência concreta, diante de outros corpos cujos afetos se mostram irredutíveis e contrários: marca a pluralidade do político. A identificação coletiva, por meio do conflito, náo é determinada pelo par amigo e inimigo, identidade e alteridade, mas pelo tipo da relação que se instaura, isto é, uma relação marcada pela diferença e violência. Este é o Leitmotiv schmittiano, e a coerência do político, segundo nosso argumento, depende da compreensão dessa questão. Para Schmitt, embora o político seja caracterizado por ser uma relação polêmica e extrema, não há identificação entre político e guerra, todavia, uma pressuposição sempre presente, pois a guerra não é o objetivo, mas o pressuposto, como possibilidade real, é "a realização extrema de inimizade [...] tendo antes que permanecer existente como possibilidade real." (SCHMITT, 2002, p. 33). A eventualidade do conflito garante o político como trágico, 
porém, não belicoso, porque, embora a guerra seja um ato político, este não é a origem da política, mas a disposição à guerra a que Schmitt se refere, em suma, como pólemos. Nesse contexto, interessa para Schmitt a demonstração da originariedade desse pólemos que caracteriza o político, ou seja, a polemicidade concreta que se manisfesta no conflito que póe em jogo vida e morte e, por conseguinte, mobiliza o ser humano numa dimensão originária existencial (seinsmäßige Ursprünglichkeit):

A guerra, disposiçáo para a morte por parte dos homens em combate, a morte física de outras pessoas que estão do lado do inimigo, nada disso tem um sentido normativo e sim apenas um sentido existencial, mais precisamente na realidade de uma situação do combate real contra um inimigo real e não em quaisquer ideais, programas ou normatividades. Não há nenhum fim racional, nenhuma norma por mais correta que seja [...] nenhuma legitimidade ou legalidade que possam justificar o fato de que, por sua causa, os seres humanos se matem uns aos outros. Se tal extermínio físico da vida humana não ocorre a partir da afirmaçâo fática da própria forma existencial perante uma negação igualmente fática dessa forma, esse extermínio não pode ser justificado. (SCHMITT, 2002, p. 49-50).

Nesse excerto, Schmitt argumenta sobre o caráter pragmático do político: não há normas nas quais se possa fundamentar a ordem política, pois o político carrega essa contingência originária consigo, qual seja, é, para além de legalidades ou legitimidades, o ato concreto que institui polemicamente a ordem diante do desafio posto pela decisão contra um inimigo ou ameaça. Para ele, a decisão polêmica sobre a exclusão, sem fundamentos normativos, justifica a existência da unidade política. Na verdade, o político é determinado pela possibilidade do conflito e pela decisáo sobre a guerra, demonstrando o trágico realismo como sua condição: apesar de não o caracterizar enquanto tal, a possibilidade real e presente da morte física torna-se o momento fundamental da vida humana, sobretudo, para a formação da identidade polêmica via dissenso. Ao afirmar, na sequência do texto, que não se pode fundamentar guerra alguma com normas éticas ou jurídicas, Schmitt propõe a tese do político como uma tese pragmática: as relaçóes concretas de poder, afetos e violência determinam o corpo político, porque

na realidade concreta da existência política não reinam ordens e normas abstratas, sendo, ao contrário, sempre pessoas ou associaçóes concretas que governam outras pessoas e associaçôes concretas, também aqui, naturalmente, visto de uma perspectiva política, o 'domínio' da moral, do direito, 
da economia e da 'norma' possui apenas um sentido político concreto. (SCHMITT, 2002, p. 72).

Ora, este é o incômodo que as teses do realismo político causam. Entretanto, o argumento acerca do político, em Schmitt (e sua aproximação ao conceito de impolítico), tem como principal vantagem a consideração da desestalização da política de um ponto de vista não liberal ou antiliberal, sem implicar uma despolitização, isto é, ainda se opondo às neutralizaçóes econômicas e técnicas, através da compreensão do político como diferença e antagonismo. Parece-lhe incontornável a problemática relação entre racionalidade e ação: não há uma finalidade, valor ou forma jurídica a ser realizada, pela qual se alcança a legitimidade ou justificação como adequação entre ação e razão ou moral. Pelo contrário, o aspecto impolítico do das Politische reside na direçáo da ação, a partir dela mesma como afeto de conservaçáo/expansáo do corpo político, isto é, a teoria do político como relação e antagonismo desconstroi a metafísica política e recoloca a questão do sentido da ação na finitude, tomando o político no seu caráter concreto e afetivo. A crítica às políticas das transcendências desempenha a mesma função da crítica ou desconstrução da metafísica tradicional, especialmente quanto à relação entre racionalidade e ação, desconstruída pela compreensão da ação política na diferença, não como cisão de instâncias ou identidades essenciais: a pergunta sobre a validade da ação, afinal, é metafísica e pressupôe a articulação bipolar entre transcendência e imanência que, nesse momento, Schmitt rejeita - bem como sua teologia política - e, para considerar apenas a constituição como abertura e pluralidade, o argumento refaz a distinção entre ser e aparecer por outra, ou seja, a distinção entre política e político, mesmo à custa da semântica política tradicional. Além disso, ao realizar essa manobra, Schmitt logra inesperada virtude, ao indicar a distinção entre transcendência e imanência: a política ou ordem como resultado dos corpos e afetos em conflito náo é outra coisa do que arranjos hegemônicos dessas relaçóes concretas. Se há transcendência ou paradigma a ser considerado como legitimador, não é outro senão a própria imanência; se há configuração de ordem e unidade, estas derivam das relaçôes de antagonismos e, por isso, se dão na imanência e qualquer transcendência, por exemplo, unidade política ou ordem jurídica, dá-se na e a partir da imanência, porque, uma vez achatadas em uma só esfera, elas se mostram coextensivas. Ação e fundamento se confundem: não cabe a pergunta se a ordem vale ou não vale, mas se ela existe ou não existe. 
O impolítico em Schmitt faz referência ao vazio originário, impossibilidade normativa ou falta e lacuna: assume a constituição da ordem no plano imanente como precária, contingente, e impede a compreensão da decisão ou coação à ordem: ao invés da transposição institucional guiada por uma forma representativa e, por conseguinte, legitimadora no sentido normativo, o impolítico não pretende preencher essa lacuna ou vazio originário, pois seria cometer o erro da teologia política. Assim, afasta-se da simetria decisão-representação, teologia e secularização, além de problematizar a relação entre imanência e transcendência, ao elaborar uma espécie de política da imanência, a qual determina o das Politische, por meio da noção de relação e afetos, ao invés de uma substância ou essência. Desse modo, o político pode referir-se a qualquer atividade, desde que estabelecida por uma referência à relaçóes concretas, isto é, nem abstratos nem universal ou a priori: "Contraposições religiosas, morais, entre outras, intensificam-se como contraposiçôes políticas e podem provocar o agrupamento do tipo amigo-inimigo; porém, se ocorrer este agrupamento de combate, a contraposição que dá a medida deixa de ser puramente religiosa, moral ou econômica, mas sim política" (SCHMITT, 2002, p. 36). Isso significa que a politização das relaçôes humanas seria dada por uma relação cujo conhecimento é sempre post factum ou in re. A postura antiessencialista provoca uma imprevisibilidade do fenômeno e o torna indelimitável. Não é outro o motivo pelo qual Schmitt prefere o adjetivo "político" ao substantivo "política", porque o que interessa não é uma esfera de coisas políticas, porém, relaçôes políticas, delimitando a ação não como uma questão de normas, mas de afetos e diferença.

\section{CONSIDERAÇÓES FINAIS}

$\mathrm{Na}$ teoria do político, Schmitt assume que a cisão entre transcendência e imanência ou ser e dever-ser é uma impossibilidade: a autoridade não recebe legitimidade, a partir de uma instância ideal. Assim, o político possui sua origem em outro lugar: na contingência, como relação polêmica estabelecida por meio da exclusão e da diferença. O factum brutum do político como hostilidade originária entre amigos e inimigos refere-se à distinção do corpo político e aos afetos, ao contrário das normas e parâmetros universais, inserindo a violência como constitutiva da ordem. Se, com Schmitt, percebe-se a ausência de substância e o conflito como pressuposto político da política, tal como um transcendental finito, a relação inesgotável entre política e política abre espaço para consideraçôes acerca de uma dialética negativa em política. Esposito não 
chega a essa compreensão; a rigor, nem mesmo Schmitt, porém, se impolitico, para aquele, significa que "o único modo de conter o poder é reduzir o sujeito" (ESPOSITO, 1999, p. 21), segundo a leitura exposta, Schmitt deixa entrever essa tese avant la lettre: a relação concreta e não o sujeito constitui a ordem.

Nesses termos, se é possível compreender Schmitt como um impolítico, também é possível antecipar a crítica espositiana à contribuição schmittiana a esse conceito: a ânsia da decisão e da ação, mesmo relativizada no final da República de Weimar, ainda perpassa seu pensamento demasiadamente moderno, tanto quanto a pretensão de unidade. A crítica impolítica à teologia política e à representação passa pela afirmação da finitude, pela ausência de forma ou de bem na imanência e pela escavação da transcendência como abertura da/na imanência. Para Esposito, seguindo as teses de Simone Weil e Georges Bataille, o bem seria irrealizável; apesar disso, o homem deveria praticar tal impossibilidade, evitando a ação. Essa ação passiva ou ação sem finalidade transcendente mostra que qualquer relação entre política e verdade se torna unilateral ou idolatria e, reduzindo-se à experiência interior - no caso, como rompimento do estatuto metafísico do sujeito de ação -, transforma-se em um misticismo traduzido como nada ou silêncio e não na possessão violenta ou externa de um objeto ou ação constitutiva de ordem: o impolítico como uma inação e, por conseguinte, como desconstrução da categoria de sujeito, num eloquente deslocamento da política moderna, que abre o pensamento da comunidade desenvolvido por Esposito contra a metafísica do sujeito.

Assim, a questão da imediação e da irrepresentação contra a mediação e a representação persiste no impolítico de Esposito e revela o ponto fraco do impolítico schmittiano: o fetiche conservador em relação ao Estado ou qualquer tipo de ação ordenativa ou instituição como resultado necessário do político. De fato, apesar de o das Politische aproximar-se do impolitico, não há uma identidade entre os termos: enquanto aquele é caracterizado por ser relacão e imanência, diferença e conflito, bem como por ser a condição originária da política, o impolitico, ao contrário, é o outro da política que coincide com ela mesma. Esposito realiza com o impolitico uma tarefa apenas entrevista por Schmitt: se este pensou a política moderna como despolitização, a ponto de lançar mão do argumento do político como reconhecimento do estádio terminal da política (isto é, dissolução da representação e, por conseguinte, perda de legitimidade e esvaziamento), Esposito foi mais radical: com o impolítico, pensa uma contra-história da modernidade, que o possibilita abordar a política moderna no confronto com sua origem aporética: a communitas. 
O mérito de Esposito é buscar, no rastro de pensadores como Elias Canetti e Simone Weil, Heidegger e Bataille, a possibilidade do impolítico sem os conceitos tradicionais de liberdade, igualdade etc. $\mathrm{O}$ ponto negativo: parte da solução estava bem mais próxima do que pensava (ou gostaria), por isso, ou bem utilizou subrepticiamente o argumento schmittiano ou bem, para evitar polêmicas com uma relação tão próxima a um autor de má fama, preferiu de maneira elegante construir um conceito e, por precaução, tornar subjacente a influência do jurista alemão.

LIMA, D. R. From the impolitico to das Politische: notes on an absent dialogue between Roberto Esposito and Carl Schmitt. Trans/form/ação, Marília, v. 41, n. 2, p. 95-118, Abr./ Jun., 2018.

\begin{abstract}
This article analyzes Roberto Esposito's idea of the impolitico, with the aim of showing the relation between the impolitical and Carl Schmitt's das Politische. Schmitt is examined in terms of the impolitical tradition reconstructed by Esposito, and the impolitical characteristics of das Politische are discussed. We then argue that Esposito gives a refined interpretation of Schmitt, solving some problems regarding transitions in Schmitt's work the 1920s, but that Esposito ends up obliterating Schmitt's influence. We propose a reading, which separates Schmitt from political theology by linking him to the impolitical tradition and which drafts the relation between the impolitico and das Politische.
\end{abstract}

KeYwords: Impolitical. Neutralization. Political. Antagonism.

\title{
REFERÊNCIAS
}

ARDITI, B. On the Political: Schmitt contra Schmitt. Telos, Nova Iorque, n. 142, p. 7-28, primavera, 2008.

ESPOSITO, R. Categorie dellimpolitico. 2. ed. Bologna: Il Mulino, 1999.

HOFMANN, H. Legitimität gegen Legalität: Der Weg der politischen Philosophie Carl Schmitts. 4 ed. Berlim: Duncker \& Humblot, 2002.

MANN, T. Betrachtungen eines Unpolitischen. 2. ed. Frankfurt am Main: Fischer, 1974.

MARCHART, O. Politische Theorie als Erste Philosophie: Warum der ontologischen Differenz die politische Differenz zugrunde liegt. In: BEDORF, T.; RÖTTGERS, K. Das Politische und die Politik. Berlim: Suhrkamp, 2010. p. 143-158.

SCHMITT, C. Glossarium. Aufzeichnungen der Jahre 1947-1951. Berlim: Duncker \& Humblot, 1991. 
. Positionen und Begriffe. 4. ed. Berlim: Duncker \& Humblot, 1994.

. Der Begriff des politischen. 6. ed. Berlim: Duncker \& Humblot, 2002.

. Verfassungslehre. 9. ed. Berlim: Duncker \& Humblot, 2003.

. Politische Theologie. Vier Kapitel zur Lehre von der Souveränität. 8. ed. Berlim:

Duncker \& Humblot, 2004.

. Römischer Katholizismus und politische Form. 5. ed. Stuttgart: Klett-Cotta, 2008.

VOEGELIN, E. Die Verfassungslehre von Carl Schmitt: Versuch einer konstruktiven Analyse ihrer staatstheoretischen Prinzipien. Zeitschrift für Öffentliches Recht, n. 11, p. 89-109, 1931.

Recebido: 17/02/2016

Aprovado: 24/08/2016 